\title{
Evolutionary Overview of Central Banking in Nepal: An Account of Law and Practice
}

\begin{abstract}
Satya Narayan Kalika*

There are a number of legal and non-legal research works done in regard to analyzing the powers, functions and roles of Central Banks. However, there is the need of a study on the evolutionary aspects of central banking laws and practices. This study aims to fulfill that purpose by giving an account of the historical and evolutionary development of central banking in Nepal. It highlights both the law and practice parts of the evolution of central banking, and gives an account of the major laws and their enactments.
\end{abstract}

Key words: Central Banking, Money, Nepal Rastra Bank, Regulation, Central Bank Independence

\section{Introduction}

A Central Bank is an independent, national-level regulatory authority that regulates banks and financial institutions, determines monetary policy, provides financial services and conducts economic research with the goals of stabilizing the nation's currency, keeping the unemployment rate low, and preventing inflation. In the words of K. K. Dewett, ${ }^{*}$ the Central Bank is a symbol of financial sovereignty and stability of the country; it is an institution which is responsible for safeguarding the financial stability of the country.

The idea of a Central Banking was developed and expanded only when the importance of issuing notes and coins was felt, i.e. to act as banker of the government and to play role of agent of the government to oversee monetary policy. The Central Bank's role has been increasing due to the growing economic independence of the country, greater necessity of management and control of the monetary system, currency and exchange matters in international trade, time-to-time economic depression and cyclical fluctuations, as well as the need for the regulation of commercial banking activities in any country. Thus, Central Bank is the institution which can coordinate, control, regulate and manage conflicting factors, economic and financial complications, which may affect the economic stability in the national and international sectors.

* * Advocate; Assistant Professor of Law, Tribhuvan University, Shanker Dev Campus.

Dewett, K.K. and Akhtar, S.M. (1978). Modern Economic Theory. Delhi: S. Chand and Co., 456. 
Central Banking is the business activity of a Central Bank - e.g. the rate of interest charged by a bank for lending money is fixed by the Central Bank in any country. Thus, central banking is not merely the job of ideally looking at what goes wrong with the credit and financial machinery of the country, but is to take such responsibilities on the shoulders of central bank and regulating the monetary system.

'Central banking' refers to the acts of discharging the functions of a central bank. There are certain characteristics of Central Banking, which are as follows:"*

- $\quad$ Serving as a banker's bank

- $\quad$ Serving as government's bank

- Monopoly in currency issue

- $\quad$ Formulating of monetary policy

- Determining foreign exchange

- $\quad$ Regulating commercial banks

For the attainment of these purposes, the Central Bank may issue unified directives in matters relating to corporate governance, 'fit and proper test' for the promoters and directors of banks and financial institutions, transparency mechanism, disclosure of potential conflict of interest, compliance, qualifications of CEO, directors and officials of the banking company, international best practices, etc.

Issue of currency notes and minting of coins is another major function of a central bank. Although the first central bank in Nepal was established just sixty-four years ago (i.e. Nepal Rastra Bank in 2013, the function of issuing coins and notes was already being carried out by other instrumentalities of the government even prior to that.

The history of coin minting in Nepal dates back to about early sixth century. The Lichchhavi King Mandeva had issued coins named 'Mananka' in 521 BS. At that time, the minting of coins of different materials such as gold, silver, copper, aluminium, leather, soil, etc. was practiced in different reign of rulers like Gopal, Mahishpal, Kirant, Lichchhavi, Malla and Shah rulers.

Regularly publishing economic statistics such as monetary policy report, statistical report of banking transactions, etc., with the view of regulating and facilitating the monetary sector of the country is also an important central banking function. These functions have been evolved in the course of time; with the rise of new challenges and opportunities in the banking sector, new functions of central banking have been developed.

\section{Statement of the Problem}

There are several research works done in regard to analyzing existing duties, roles, powers and functions of central banks, surveying existing legal frameworks on central banking,

** Kalika, S.N. (2020). Banking Law in Nepal. Kathmandu: Buddha Publications, 43. 
and also their impact in the banking business. However, there lacks the research works on the historical evolution of central banking laws and central banking practices and their development. This research venture aims to fulfill such gap. The questions pertaining to the genesis, evolution and development of central banking in Nepal are expected to be answered by this article. Similarly, what are the major legislations contributing to the development of central banking in Nepal is also another question to be answered by this study. The principal focus of this study is to overview the central banking activities in Nepal, as well as to discuss the major laws and rules promulgated in Nepal pertaining to central banking.

\section{Objectives of the Study}

The objectives of this study are:

i. $\quad$ to survey the major evolutionary events of central banking in Nepal;

ii. to discuss the major legislations contributing to the development of central banking in Nepal

\section{Research Methodology}

This work is of doctrinal nature. The methodology followed is historical, descriptive, comparative and analytical. Here has been made an attempt to describe and analyze the issues of central banking based on qualitative data available in laws, rules, books, articles and treatises, in addition to the legal frameworks contained in the banking legislations of Nepal. The data collected are from both primary and secondary sources. The data from primary sources have been derived from Acts of Parliament such as Nepal Rastra Bank Act, 2058, Nepal Rastra Bank Act, 2012, Bank and Financial Institution Act, 2063, Banks and Financial Institutions Act, 2073; while the data from secondary sources are drawn from the books, articles, reports and other secondary sources of legal works. APA method has been used to cite sources, and being a legal research, footnote system has been followed.

\section{Review of Literature}

Central banking encompasses various banking laws from coin issue in the early periods through the present latest banking systems. It is a country's leading banking responsibility for issuing and operating currency, implementing monetary policy, overseeing the banking system, acting as a 'clearing banker' for the commercial banks and playing role of bank of last resort. Many central banks are responsible for handling the government's budgetary accounts and for managing the country's external monetary affairs, in particular the exchange rate. ${ }^{* * *}$

Awatar Neupane, in his book Banking Law, ${ }^{* * * *}$ has a separate chapter on Central Bank, and discusses in brief the first few banking laws of Nepal. He has ably mentioned in his book about the establishment, composition, powers, functions and roles of Nepal Rastra Bank. However,

\footnotetext{
*** Pass, C. (2006). Collins Dictionary of Business (3 ${ }^{\text {rd }}$ ed.). Glasgow: Harper Collins Publishers, 69. **** Neupane, A. (2019). Banking Law. Kathmandu: Pairavi Book House, 78.
} 
the book does not contain a proper account of the evolution and historical development of central banking in Nepal.

De Kock gives a notable definition that 'A Central Bank is a bank which constitutes the apex of the monetary and the banking structure. It is the lender of last resort and has monopoly in bank notes.' Central Bank is a symbol of financial sovereignty and stability of the country. It is an institution which is responsible for safeguarding the financial stability of the country (Dewett, K.K., 1978). R.P. Kent explains 'Central Bank as an institution which is charged with responsibility of managing the expansion and contraction of the volume of money in the interest of the general public welfare'."

Bijay Nath Bhattarai, the then Governor of Nepal Rastra Bank, in his article Nepal Rastra Bank: A Journey of Fifty Years, ${ }^{\text {nighto }}$ hights the historical development of Nepal Rastra Bank and the then political context. He highlights how the basis of the establishment of Nepal Rastra Bank was rooted in the rudimentary financial and monetary system of Nepal in the 1950s which was characterized by an environment of dual currency - Nepalese and Indian currencies, and the NRB was established also with a purposes to widen the circulation of Nepalese currency and to stabilize the exchange rate of Nepalese currency vis-à-vis the Indian currency. However, this article has not covered the evolutionary and historical development of central banking in Nepal prior to the establishment of Nepal Rastra Bank, nor has it kept in its purview the analysis of major laws related to central banking.

\section{Evolution of Central Banking}

The Sveriges Riksbank (commonly known just as Riksbank) of Sweden is regarded as the world's first Central Bank. It is also the third oldest bank in the world with continuous operation. The Riksbank, established in 1668, became the first Central Bank 'by banking practice'. The Bank of England, established in 1694, however, is the first Central Bank to be established 'by virtue of a statute'. Napoleon Bonaparte of France created the Banquet de France (meaning, Bank of France) in 1800. In Germany (the then German Empire), the Reksbank (meaning, Bank of the Realm) was established in 1876. It was replaced by separate central banks for East and West Germanys after the Second World War. The current German Central Bank is the Deutsche Bundesbank.

In the United States, the U.S. Congress established the Federal Reserve System in the year 1913 for the purpose of economic stability in the United States by introducing a Central Bank to oversee monetary policy. Similarly, in Canada, the Bank of Canada was established in 1935.

\footnotetext{
***** C/F Bhandari, D.R. (2059). Banking and Insurance: Principle and Practice (2 ${ }^{\text {nd }} \mathrm{ed}$.). Kathmandu: Ayush Prakashan, 38.

$* * * * * * \quad$ Bhattarai, B.N. (2005). Nepal Rastra Bank: A Journey of Fifty Years. Milestone. Kathmandu: Nepal Rastra Bank, 81.
} 
The European Central Bank, established in 1998, is the central bank for the Euro and administers monetary policy within the Eurozone. The U.S. Federal Reserve System, the Bank of England, the Bank of Japan and the European Central Bank are sometimes also referred to jointly as "the Big Four" central banks in the world for their importance and influence.

\section{Nomenclature of Central Bank}

A Central Bank can be known by various names, varying from country to country. In Nepal, it is called Nepal Rastra Bank. In countries like India, Australia, New Zealand, Vanuatu, Fiji, South Africa, Zimbabwe, Malawi, etc., it is also known as Reserve Bank (e.g. Reserve Bank of India (RBI)). The Central Banks of countries such as Afghanistan, Argentina, Armenia, Bahrain, Belize, Bolivia, Brazil, Yemen, Taiwan, Uruguay, Turkey, Sri Lanka, Qatar, UAE, Malaysia, Samoa, Paraguay, Nigeria, etc. are simply known as 'Central Bank' (e.g. Central Bank of Malaysia).

In countries like Pakistan and Vietnam, the Central Bank is called 'State Bank' (e.g. State Bank of Pakistan). The Central Banks of countries like Tajikistan, Rwanda, Belarus, Cambodia, Georgia, North Macedonia etc. are called 'National Bank' (e.g. National Bank of Tajikistan). And in countries like Russia, South Sudan, Thailand, Canada, Albania, Indonesia, Japan, South Korea, United Kingdom, etc., the Central Banks are called 'Bank of (the country's name)' (e.g. Bank of England).

Certain countries like Bhutan, Brunei, Maldives, Palestine, Saudi Arabia, Singapore, etc. have the name 'Monetary Authority' for institutions performing Central Banking functions (e.g. Royal Monetary Authority of Bhutan). In the United States, however, the Central Banking system is instead called the Federal Reserve System. However, certain countries, mostly which are micro-nations or small islands, have no Central Bank at all. Monaco, Nauru, Kiribati, Micronesia, Palau, etc. are the examples of countries without a Central Bank.

\section{Evolutionary Background of Central Banking Law}

American writers Jonathan R. Macey and Geoffrey P. Miller write, "By 'banking law' we mean not only the law applicable to traditional commercial banks, but also the pattern of regulation governing other depository institutions such as savings and loans, savings banks

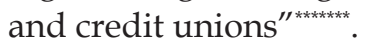

In 1397 'Medici Bank of Florence' established and was in operation until 1494. It was the founding organization of the Bank of England in 1640, which is marked the beginning of modern banking system in Britain. The Bank of England was the first central bank established by virtue of a charter (law).

******* Macey, J.R. and Miller, G.P. (1997). Banking Law and Regulation. New York: Aspen Law \& Business, xxv.

******** Tannan, M.L. (2016). Banking Law and Practice in India (23 ${ }^{\text {rd }}$ ed.). Gurgaon: Lexis Nexis, 3. 
Likewise, the Peels Act, 1844; Financial Services and Markets Act, 2000; Financial Service Act, 2012 are the important banking laws of England. In 1786, General Bank of India and the Bank of India were established. Then Negotiable Instrument Act, 1881 enforced; Avadh Commercial Bank was establishment in the same year; and in 1935, Reserve Bank of India was established under the Reserve Bank of India Act, 1935.

Evolutionary Development of Central Banking in Nepal

The history of development of Central Banking in Nepal can be divided into four phases: -

1. $\quad$ First Phase (before 1993 B.S.)

2. $\quad$ Second Phase (1994 B.S. to 2012 B.S.)

3. $\quad$ Third Phase (2013 B.S. to 2058 B.S.)

4. $\quad$ Fourth Phase (2058 B.S. to the present)

FIRST PHASE (before 1993 B.S.): Money is the basis of establishment of central banking. In the eastern society, Manusmriti is the Hindu scripture that contains the rules regarding the transaction of money and loan, and recovering the loan with interest. Kautilya ko Arthashartra (300 BC) contained the matters regarding currency and its transactions. Similarly, Mahabharat is another Hindu inscription, contains about Vriddhipajivi, the then money lender was involved in money lending transaction. In the Ramayana, Ram had managed Vriddhipajivi at the time of returning home from 14 years of Jungle-residence.

Below is a brief survey of money and central banking practice in different periods of Nepal. It is depicted in the following table.

Table No. 1: Practice of Money and Banking in different periods of Nepal

\begin{tabular}{|l|l|l|l|}
\hline Era & Monetary and Banking Practices & $\begin{array}{l}\text { Ruler behind the } \\
\text { development }\end{array}$ & $\begin{array}{l}\text { Time } \\
\text { Period }\end{array}$ \\
\hline $\begin{array}{l}\text { Pre-historic } \\
\text { period }\end{array}$ & $\begin{array}{l}\text { Transaction of money, barter, and } \\
\text { circulation loan with interest. }\end{array}$ & King \& society & $\begin{array}{l}\text { Before } \\
521 \text { BS }\end{array}$ \\
\hline \multirow{2}{*}{ Lichhavi Era } & Mananka coin & King Manadev & 521 BS \\
\cline { 2 - 4 } & Gunanka coin & King Gunakamdev & 780 BS \\
\cline { 2 - 4 } & $\begin{array}{l}\text { Payment of dues of the public, } \\
\text { start of (Nepal Sambat) }\end{array}$ & $\begin{array}{l}\text { Shankhadhara Shakhwa, a } \\
\text { Businessman }\end{array}$ & 937 BS \\
\hline Malla Era & Copper coins & King Ratna Malla & 1484 BS \\
\cline { 2 - 4 } & Mahindra Malli & King Mahindra Malla & 1561 BS \\
\hline
\end{tabular}




\begin{tabular}{|l|l|l|l|}
\hline Shah Era & Kausi Tosha Khana \& Taksar & King Prithvi Narayan Shah & 1889 BS \\
\cline { 2 - 4 } & Tejaratha Adda & PM Ranoddip Singh & 1934 BS \\
\cline { 2 - 4 } & $\begin{array}{l}\text { Nepal Bank Kanoon, 1994 and } \\
\text { Nepal Bank Limited }\end{array}$ & PM Juddha Shumsher & 1994 BS \\
\cline { 2 - 4 } & Sainik Drabya Kosh & PM Juddha Shumsher & 1996 BS \\
\cline { 2 - 4 } & Sadar Muluki Khana & PM Juddha Shamsher & 1999 BS \\
\cline { 2 - 4 } & $\begin{array}{l}\text { Nepal Rastra Bank Act, 2012 and } \\
\text { Nepal Rastra Bank }\end{array}$ & King Mahendra & 2013 BS \\
\hline
\end{tabular}

The history of monetary transaction and minting metal coins in Nepal can be traced back to early sixth century B.S., Lichhavi dynasty date which was made from different materials-gold, silver, copper, aluminium, lather, etc. The coin named Mananka of Mandev, Gunanka of Gunkamadev, Mahindra Malli of Mahendra Malla, Copper Coin issued by Ratna Malla in Mediaval period were the notable coin history of Nepal. 'Tankadhari' was one of the business community among 64 classes of Nepalese society as classified by Jayasthiti Malla, were the traditional goldsmiths who traded in currency and provided money on credit for business, family loan and international trade. Shankhadhara Shakhwa, a businessman in Kantipur discharged all the loans of then country and made free all people of the country in 937 B.S. At $9^{\text {th }}$ century of Vikram era, 'Taksali' was established to manage currency in Kantipur.

'Taksar', the workshop for making coin was established by King Prithvi Narayan Shah and managed to issue currency in his name in 1889. The office of 'Kausi Tosha Khana' was established as a banking agency by the King Shah. At the time of second Rana Prime Minister Shree Teen Ranoddip Singh had established 'Tejaratha Adda' for the purpose of providing loan to the government officials against $5 \%$ interest rate. But there was no concept of source of collecting deposits from the general public to raise funds except once funded by the government. It was the first formal banking structure, and deems as pre-form of modern organized banking in Nepal. After six decades, Nepal Bank Limited was founded on its basis.

The history of Central Banking started gradually in the world by delegating certain Central Banking authorities such as issue of currency, determination of monetary policy, formulating

******** A coin issued by Lichhavi King Manadev in 521 B.S. named Mananka is one of the sources Nepalese histories.

******** His ruling period was between 1934 B.S.-1942 B.S., during the reign of King Prithvi Bir Bikram Shah.

******** Shrestha, D. (2054). Nepalma Prayogatmak Banking (3 ${ }^{\text {rd }}$ ed.). Kathmandu, Sajha Prakashan, 1. 
policy for foreign currency, regulating commercial banking activities, etc. by the state/ government/monarch to the Central Bank or other such Central-Banking-institution.

In a similar manner, the history of organized Central Banking in Nepal traces back to the establishment of Nepal Rastra Bank on the basis of its constituting statute - the Nepal Rastra Bank Act, 2012.

SECOND PHASE (1994 B.S. - 2012 B.S.): This phase dates from the establishment of Nepal Bank Limited by the enactment of Nepal Bank Kanoon, 1994, to the enactment of Nepal Rastra Bank Act, 2012. However, it must not be forgotten that there were several other banking/ financial instrumentalities of the government prior to 1994 (for example, the Sadar Muluki Khana, Tejarath Adda), which performed certain central banking roles such as the issuing of coins.

\section{Nepal Bank Limited (under Nepal Bank Kanoon, 1994 B.S.)}

Nepal Bank Limited was the first modern organized bank of Nepal which was established in 1994 B.S. It was incorporated under the Nepal Bank Kanoon, 1994. At that time, Nepal Bank was active not only as a commercial bank but was also playing the role of a government bank and a Central Bank. However, the Kanoon (called 'Act' in present terms), its constituting document, did not have a mention of any such provision/feature to expressly denote the Bank as a Central Bank, yet it can impliedly be understood that Nepal Bank used to perform central banking roles. This was during the Rana regime under Prime Minister Juddha Shumsher when industrialization was recently initiated in Nepal after enactment of Company Kanoon, 1993.

\section{Sadar Muluki Khana}

Nepali bank notes were issued in 2002 and 2009 B.S. before establishment of Central Bank by the Sadar Muluki Khana. It was the Treasury Department of government of Nepal as Nepal did not have a Central Bank at that time. The banknotes were signed by Narendra Raj Pandit, a Khajanchi was head of the treasury department. The Muluki Khana was led by Janakraj Pandit, Rudraraj Pandit and Narendra Raj Pandit.

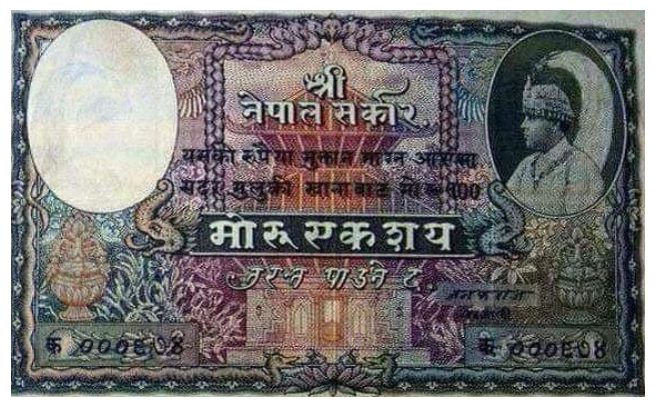

Nepalese Currency issued in 2002 B.S. prior to the establishment of NRB

******** The photo credit goes to Suman Kamal Parajuli, Associate Professor of Management, Tribhuvan University Shanker Dev Campus. 
The first banknotes were issued in Nepal in the year 2002 B.S. Prior to that, only coins used to be minted and circulated, and till then there was no practice of paper currency. Before the Rastra Bank enjoying the currency issuing role in 2016 B.S. (1959 A.D.), the banknotes were issued by 'Sadar Muluki Khana', such as the banknote in the picture above. It was then called 'MoRu', and had the signature of the Treasurer ('Khajanchi'), in contrast to that of a Governor. These banknotes at that time were printed in Indian Security Press in Nasik, India, and had had no security features apart from the watermark in the banknote, and the special paper in which it was printed.

THIRD PHASE (2013 B.S. to 2058 B.S.): The second phase of the evolutionary development of central banking in Nepal dates between 2012 B.S. and 2058 B.S., i.e. after the enactment of Nepal Rastra Bank Act, 2012 (under which the Nepal Rastra Bank was established in Baisakh 14, 2013 B.S.) and before the enactment of Nepal Rastra Bank Act, 2058.

Nepal Rastra Bank Act, 2012

The basis for the establishment of Nepal Rastra Bank was rooted in rudimentary financial and monetary system of Nepal in the 1950s which was characterized by an environment of dual currency - both Nepalese and Indian currencies circulating side by side, where the exchange rate between both currencies were also unstable."

In order to control the prevailing instability in the monetary sector and with the aim of creating a new, specialized Central Bank, the Nepal Rastra Bank Act, 2012 was enacted. It was drafted by a committee chaired by the then Principal Royal Advisor Sardar Gunjaman Singh. The draft was promulgated as a law on Kartik 18, 2012 B.S - i.e. the Nepal Rastra Bank Act, 2012 (1955). 2013 B.S. (April 26, 1956 A.D.) as a national Central Bank."

The major objectives of the Nepal Rastra Bank Act, 2012 were:"

- $\quad$ To widen the circulation of domestic currency

- $\quad$ To stabilize the exchange rate between the Nepalese and Indian Currencies

- To expand the banking network in the country,

- $\quad$ To evolve policy instruments for monetary management.

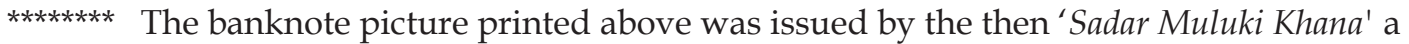
Government owned body established in 1999 B S, and the notes were circulated by Nepal Bank Limited.

******** Bhattarai, B.N. (2005). Nepal Rastra Bank: A Journey of Fifty Years. Milestone. Kathmandu: Nepal Rastra Bank, 81.

******** Neupane, A. (2076). Banking Law. Kathmandu: Pairavi Book House Pvt. Ltd., 79.

******** Nepal Rastra Bank Act, 2012, Section 3.

******* Nepal Rastra Bank Act, 2012, Preamble. 
After its establishment, Nepal Rastra Bank undertook the Central Banking role which was earlier, by practice, played by Nepal Bank Limited and other government departments. Nepal Rastra Bank was established to supervise, promote and direct the functions of commercial banking activities. The NRB is a non-profit organization fully owned by the Government of Nepal. It has the sole right to issue currency and is responsible to manage the country's foreign exchange reserves.

The NRB did not start issuing banknotes immediately after its establishment in 2013 B.S. (1956 A.D.). It started issuing banknotes only from Ashwin 3, 2016 B.S. (September 19, 1959 A.D.). The Nepalese Currency printed and issued by the NRB was still called ' $M o R u$ ', as depicted in the image below:

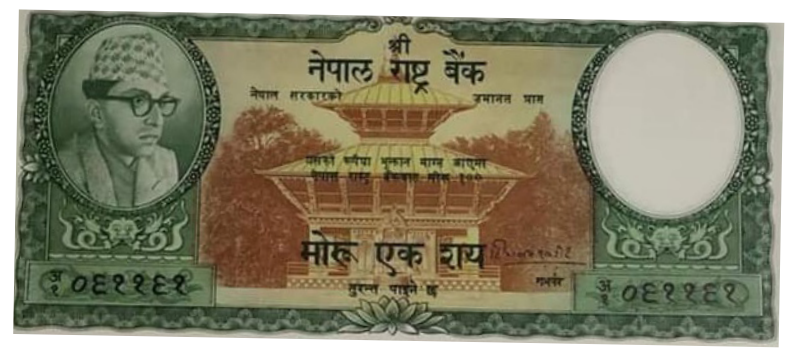

Nepalese Currency issued by the NRB in 2016 B.S.

The Nepal Rastra Bank Act, 2012 was repealed and replaced by the existing Nepal Rastra Bank Act, 2058.

FOURTH PHASE (2058 B.S. to present): The third and the current phase of the development of central banking in Nepal started after the enactment of Nepal Rastra Bank Act, 2058.

\section{Nepal Rastra Bank Act, 2058}

Nepal Rastra Bank Act, 2012 (1955) was the basis of establishing the first Central Bank in the history of modern Nepal in 2013 (1956). The new Nepal Rastra Bank Act, 2058 (2002) replaced the erstwhile Act of 2012; and further ensured the operational autonomy and independence of the Rastra Bank. It was given the royal assent on $17^{\text {th }}$ Magh 2058 (January 30, 2002).

It has repealed two laws: (a) The Nepal Rastra Bank Act, 2012 (1955) and (b) The Currencies Act, 2040 (1983). All activities carried out in accordance with the Acts repealed are deemed to have been carried out in accordance with the Nepal Rastra Bank Act, 2058. It has 12 chapters and 120 sections. The Governor is the Chief Executive Officer of the Rastra Bank, and also chairs the Board of Directors of the Bank. The Board of Directors is the apex body of policy making in Nepal Rastra Bank.

******** The photo credit goes to Suman Kamal Parajuli, Associate Professor of Management, Tribhuvan University Shanker Dev Campus. 
This Act was amended twice: (i) Nepal Rastra Bank (First Amendment) Act, 2063 BS (2006) (on 2063.07.23 (Nov. 9, 2006)); (ii) Nepal Rastra Bank (Second Amendment) Act, 2073 BS (2016) (on 2073.07.29 (Nov. 14, 2016)). Apart from this, several other 'amending legislations' have amended certain parts of this Act, albeit without substantive changes.

\section{Nepal Rastra Bank as a Central Bank}

In Nepal, the job of Central Banking has been being performed by Nepal Rastra Bank from the period of its establishment. The Nepal Rastra Bank Act, 2058 clearly contains that, there shall be a Central Bank established in the name as Nepal Rastra Bank in order to carry out the functions of Central Bank. The Preamble of Nepal Rastra Bank Act, 2058 clearly mentions that the priorities and purposes of establishment of Rastra Bank are to discharge the functions as the Central Bank of Nepal, which is as follows:

- To formulate necessary monetary and foreign exchange policies, and to maintain the stability of price;

- To consolidate balance of payment for sustainable development of the economy of the Kingdom of Nepal, and to develop a secure, healthy and efficient system of payment;

- To appropriately regulate, inspect and supervise in order to maintain the stability and healthy development of BFI system;

- $\quad$ For the enhancement of public credibility towards the entire banking and financial system of the country

\section{The Banks and Financial Institutions Acts of 2063 and 2073}

While the Nepal Rastra Bank Act, 2058 had already given a wide range of powers to Nepal Rastra Bank as a Central Bank. The Banks and Financial Institutions Act, 2073 has been further elaborated and strengthened the central banking role of the Rastra Bank, in connection to bank regulation and supervision of the BFIs. The draft was prepared by the taskforce coordinated by the NRB Executive Director Bhaskar Mani Gyawali. The Bill was tabled in the Parliament in 2014. Lately, the Bill was passed by the Parliament on Poush 26, 2073 B.S. Finally, the presidential assent was given and the Act was published in Nepal Gazette on Baisakh 10, 2074 B.S., after which it came into force, and repealed the erstwhile BAFIA of 2063.

The Banks and Financial Institutions Act, 2073 has extended the power of the central bank in the areas like corporate governance. Besides, protection of right and interest of depositors, promotion of quality and reliable banking and financial intermediary facilities through the healthy competition between the BFIs, etc. are the new features of the BAFIA, 2073.

The Central Bank formed a taskforce under the coordination of the NRB's Executive Director Bhaskar Mani Gyawali to prepare a draft for the new BAFIA. The Bill was tabled in the Parliament in 2014 by the then finance minister Dr. Ram Saran Mahat, which immediately

******** Nepal Rastra Bank Act, 2058, Section 3. 
drew widespread criticism in the public media due to unreasonable involvement of some lawmakers having ownership and possibility of influence in the banks and financial institutions through the legal frameworks.

However, when the Bill was passed by the Parliament on Poush 26, 2073 B.S, it drew public attention all over again, for a wrong reason - it was 'held' by the President who had to give her assent to the passed Bill in order to turn it into an Act. The presidential assent was finally given and the Act was published in Nepal Gazette on Baisakh 10, 2074 B.S., after which it came into force, and repealed the erstwhile Banks and Financial Institutions Act, 2063.

\section{Independence of Central Bank: A Future Need}

Mostly, Central Bank is a state owned entity. Central Banks are granted certain autonomy by the law. However, being an instrumentality of the government and owned by the government, there always exist possibilities of governmental interventions in matters relating to monetary policy and other functions of the Central Bank.

A Central Bank with a high degree of discretion in conducting monetary policy would find itself under constant political pressure to boost the economy and reduce unemployment, but since the economy cannot exceed its potential GDP or its natural rate of unemployment over time, this policy would instead only lead to higher inflation in the long run. ${ }^{\text {A solution }}$ to this could be ensuring independence to the Central Bank in formulating its policies by lessening the governmental intervention as matters of both law and practice. This means that in addition to enacting legislations confirming the independence of Central Bank, the concerned government should also act in good faith as to this regard, and not put pressures on the Central Bank for political purposes or for gaining political mileage.

In Nepal, however, the Central Bank (i.e. the Nepal Rastra Bank), both in theory and in practice, is not far from the reach of governmental interventions, and thus is not as independent as the Central Banks of the above mentioned countries, although it has a certain level of autonomy as prescribed by its constituting law - the Nepal Rastra Bank Act, 2058. Prof. Goodhart, a Professor of Banking and Finance in the London School of Economics opines that the idea that 'a Central Bank might, or should, be independent of the government' is an idea who time has most certainly come. This logic is supported by examples of countries such as Venezuela, Chile, South Africa and New Zealand, who's Central Banks, have been given formal constitutional independence from the executive branch of the governments.

\footnotetext{
******** Kydland, F. and Prescott, E. (1977). Rules Rather than Discretion: The Inconsistency of Optimal Plans. Journal of Political Economy, 85(3), 473.

******** Nepal Rastra Bank Act, 2058, Section 6.

$* * * * * * * *$ Goodhard, C.A.E. (1995). The Central Bank and the Financial System, London: Macmillan Press Ltd, 60.
} 


\section{International Relations of Nepal Rastra Bank}

Nepal Rastra Bank Act, 2058 and the Bretton Woods Agreement Act, 2018 contain provisions ${ }^{* * * * * * *}$ regarding the relationship of Nepal Rastra Bank, as Nepal's central bank, with International banking organizations. The NRB has an International Relations department in its organogram to deal specifically in its international relations.

Nepal Rastra Bank has been maintaining relations with domestic, regional and international banking and financial institutions in mutual cooperation and transfer of knowledge and skills in different fields, including research and development. The NRB has cordial relations with and/or is also a member of international institutions and associations, such as IMF, World Bank, WTO, SEACEN, APRACA, etc. In addition to that, the NRB represents Nepal in international organizations and associations on the matters within the scope of its working areas. It also has the power to acquire, exercise and deal with special drawing rights of the Government of Nepal.

\section{Conclusion}

Presently, the Nepal Rastra Bank Act, 2058 and Banks and Financial Institutions, 2073 are the two major prevailing laws pertaining to central banking in Nepal. These two legislations have given the NRB wide powers in regard to carrying out the central banking powers and functions such as formulation of monetary and foreign exchange policies, issuing notes and minting coins, providing license to banks and financial institutions, supervise, inspect and regulate the banks and financial institutions in operation, act as the banker, advisor and financial agent of the Government of Nepal, act as the banker of banks and financial institutions in operation, serve as a lender of last resort, manage the system of payment, clearing and settlement, manage liquidity, etc. From the tenures of the first Governor Himalaya Shumsher JBR to the incumbent Maha Prasad Adhikari, the NRB has been actively playing the role as a central bank in performing the functions assigned to it by the Nepal Rastra Bank Act, 2058 and the Banks and Financial Institutions Act, 2073. Furthermore, the international involvements and exposures of the NRB have helped it maintain its standard at par with other foreign and international banking organizations. The evolution of banking law in Nepal has been taken into new heights by the legal frameworks and the sound practical steps taken by the NRB, thereby maintaining its standard at par with central banks of developed economies. However, on part of the independence of central bank, it is an eminent need for the future to make relevant legal changes in the Nepal Rastra Bank Act, 2058 to granting operational and functional independence to Nepal Rastra Bank. Doing so will keep the central bank away from political and administrative interventions from the government and will further enable it to carry out its central banking functions properly and independently.

******* See, Section 11 of Nepal Rastra Bank Act, 2058 and Section 7 of Bretton Woods Agreement Act, 2018. 


\section{References}

Banks and Financial Institutions Act, 2063.

Banks and Financial Institutions Act, 2073.

Bhandari, D.R. (2059). Banking and Insurance: Principle and Practice (2 ${ }^{\text {nd }}$ ed.). Kathmandu: Ayush Prakashan.

Bhattarai, B.N. (2005). Nepal Rastra Bank: A Journey of Fifty Years. Milestone. Kathmandu: Nepal Rastra Bank, 80-85.

Bretton Woods Agreement Act, 2018.

Dewett, K.K. and Akhtar, S.M. (1978). Modern Economic Theory. Delhi: S. Chand and Co.

Goodhard, C.A.E. (1995). The Central Bank and the Financial System, London: Macmillan Press Ltd.

Kalika, S.N. (2020). Banking Law in Nepal. Kathmandu: Buddha Publications.

Kydland, F. and Prescott, E. (1977). Rules Rather than Discretion: The Inconsistency of Optimal Plans. Journal of Political Economy, June, 85(3): 473-490.

Macey, J.R. and Miller, G.P. (1997). Banking Law and Regulation. New York: Aspen Law \& Business.

Nepal Bank Kanoon, 1994.

Nepal Rastra Bank Act, 2012.

Nepal Rastra Bank Act, 2058.

Neupane, A. (2019). Banking Law. Kathmandu: Pairavi Book House.

Pass, C. (2006). Collins Dictionary of Business (3 ${ }^{\text {rd }}$ ed.). Glasgow: HarperCollins Publishers.

Shrestha, D. (2054). Nepalma Prayogatmak Banking (3 ${ }^{\text {rd }}$ ed.), Kathmandu, Sajha Prakashan.

Tannan, M.L. (2016). Banking Law and Practice in India (23 ${ }^{\text {rd }}$ ed.). Gurgaon: Lexis Nexis. 


\section{Author Guidelines for Article Submission}

$\backslash$ Management Dynamics, is a peer-reviewed management journal. Submission of a paper for the Management Dynamics will be taken to imply that it represents original work not previously published or borrowed other's work. The papers so received have to undergo a blind review process and are then subject to approval by the Editorial Board.

Ideas, opinions, conclusions and critics expressed in the papers published in the Dynamics are solely those of authors and in no way represent views and policies of the Editorial Board or publishing organization. Thus, there will be no liability of the Editorial Board or publishing organization in case of any claim or critics by third party, researcher(s) should thus be accountable solely for any. The published work in Management Dynamics, will not be supposed to be published anywhere without consent of the Editorial Board.

\section{General format directions for the articles:}

1. Submitted manuscripts should be written in English, typed in double spacing with 1.5 inch margins on one side of standard paper.

2. The title page should contain the title, the name, institutional affiliation(s), position, E-mail of each author, and, in the case of co-authorship indicate the corresponding author.

3. In case the author(s) is provided grant or any type of financial support from any organization or institution, this should be spelled out clearly below the key words.

4. The manuscript should be accompanied by an abstract not exceeding 300 words, and the preferred maximum length of a submission is 10,000 words.

5. Footnotes, if any, should be numbered consecutively with superscript arithmetic numerals at the foot of each page.

6. Figures and tables should be on separate sheets and have descriptive titles.

7. References in the text should follow the author-date format following APA style. References should be listed alphabetically in the following style:

Author, A. A. (year of publication). Book title. Publisher's Location: Publisher.

Elmuti, D. (2004). The perceived impact of outsourcing on organizational performance. MidAmerican Journal of Business, 18(2), 33-42.

Baron-Cohen, S. (2015). Radical behaviorism. In J. Brockman (Ed.), This idea must die (pp. 204-207). New York: Harper Perennial.

Guest, D. (2002). Human resource management, corporate performance and employee wellbeing: Building the worker into HRM. The Journal of Industrial Relations, 44(3), 335-358.

Authors should e-mail their manuscript to: managementdynamics@shankerdevcampus.edu.np

The Editorial Board

Management Dynamics

Tel: 977-014240556 
